\title{
De Zuidelijke Nederlanden en de oprichting van de Oost- en Westindische Compagnieën
}

\author{
E. STOLS
}

De Oost- en Westindische Compagnieën gelden als belangrijke mijlpalen in de geschiedenis van de handelsorganisatie en van de koloniale expansie. Zij zijn de eerste duidelijke verschijning van de grote compagnie en zij luiden het verval van de Portugees-Spaanse koloniale macht en de opkomst van de Hollandse in. Als dusdanig wordt hun recht gedaan in alle handboeken en schetsen over economische geschiedenis en zijn zij het voorwerp geworden van grondig wetenschappelijk onderzoek. De bibliografie daarover zal wel de duizend titels overschrijden, en zou het laatste woord daarover gezegd zijn, dan zou men zeker nog een curieuze historiografie ervan kunnen schrijven.

Opvallend is zeker de internationale samenstelling van de historici die zich met het probleem bezig gehouden hebben. Weinig andere onderwerpen uit de geschiedenis der Lage Landen hebben zoveel fascinatie uitgeoefend op buitenlandse historici, van Britten tot Venezolanen, van Brazilianen tot Duitsers ${ }^{1}$. Ongetwijfeld is die belangstelling niet vrij van bijbedoelingen. De Brazilianen bijvoorbeeld leggen bijzondere nadruk op de aanwezigheid en de werking van de Westindische Compagnie in het noordoosten van hun land als een welkom alternatief voor de te exclusieve aanspraken van de Portugese geschiedschrijving op de beschaving en economische ontwikkeling van Brazilië ofwel om het slechte beheer der Spanjaarden tijdens de periode van de koningen Filips II, III en IV te brandmerken. Tegelijkertijd eisen zij de verdrijving van deze moderne Hollandse macht op als een succes voor een nog vroegtijdig nationaal gevoelen ${ }^{2}$. Wanneer de Venezolaan

* Dit artikel is de bewerking van een lezing gehouden voor het eenentwintigste NederlandsBelgisch Historisch Congres te Rotterdam op 21 mei 1971.

1. H. Waetjen, Das holländische Kolonialreich in Brasilien. Ein Kapitel aus der Kolonialgeschichte des 17. Jahrhunderts ('s-Gravenhage-Gotha, 1921); J. A. Gonsalves de Mello Neto, Tempo dos Flamengos (Rio de Janeiro, 1947); J. H. Rodrigues, Historiografia e bibliografia do dominio holandês no Brasil (Rio de Janeiro, 1949); C. R. Boxer, The Dutch in Brazil, 1624-1654 (Londen, 1957); K. Glamann, Dutch-Asiatic Trade, 1620-1740 (Kopenhagen, 1958); E. Cordova-Bello, Companias Holandesas de Navegación. Agentes de la Colonización Neerlandesa (Sevilla, 1964); M. Neme, 'A Holanda e a Companhia das Indias Ocidentais no tempo do dominio Holandês no Brasil', Anais do Museu Paulista, XXII (Sao Paulo, 1968) 9-214; idem, Formulas Politicas no Brasil Holandês (Sao Paulo, 1971).

2. Op een meer polemisch niveau wordt dat zelfs een voorbeeld voor de behandeling van de huidige buitenlandse imperialistische aanwezigheid. Zie ook de polemiek tussen Netscher en de

BMGN 88 afl. 1. 


\section{E. STOLS}

E. Cordova-Bello de economische verdraagzaamheid en de volkse deelname in de Compagnieën ophemelt, dan wil hij in contrast daarmee het gehate Spaanse monopolie treffen ${ }^{3}$. Onbetwistbaar vindt men hier een nationalistische ondertoon. Het zou interessant zijn op dit stuk de recente Indonesische geschiedschrijving en -voorstelling te onderzoeken.

Al ging zij niet zo ver, toch bestond er merkwaardigerwijs een al even nationalistisch gemotiveerde visie op de Hollandse Compagnieën bij de Belgische historici uit de negentiende eeuw en van vóór de 'Algemene Geschiedenis der Nederlanden'. Op de achtergrond schuilt de hang naar koloniën in sommige Belgische milieus uit die tijd, die zich de medewerking van Clio's dienaars verzekerden. Behept met de sluiting van de Schelde, de opheffing van de Oostendse Compagnie en het recenter verhes van de Indonesische handel na 1830, zagen deze in de Compagnieën het symbool van alle gemiste kansen en koloniale frustraties en zochten zij deze bedekte naijver te boven te komen door het Zuidnederlandse element erin sterk te benadrukken ${ }^{4}$. Zelfs H. Pirenne schreef het onverbloemd: 'Het economisch verval van België sedert het einde van de zestiende eeuw is aan het land door de Verenigde Provinciën opgedrongen'5 . Samen met de voor economische problemen onverschillige Spaanse meesters heetten deze de schuld te dragen voor het uitblijven van een koloniale handel in de zeventiende eeuw. Dit oordeel werd nog onderschreven door R. van Roosbroeck en H. van Werveke in de 'Geschiedenis van Vlaanderen', weliswaar op een reeds meer genuanceerde manier' ${ }^{6}$.

De Nederlandse historici zijn allerminst de dupe geworden van die nationalistische aanpak. Voorzeker was er enig verzet tegen de te grote accentuering van het Zuidnederlandse aandeel in de stichting der Compagnieën; terecht werd gewezen op de bloei van de Hollandse en vooral van de Amsterdamse handel van vóór de stichting en werd ook de 'pesée globale' van de Compagniehandel binnen het geheel van de economische groei in de Verenigde Provincies tot reëlere proporties teruggebracht $^{7}$.

Het is niet de bedoeling hier deze problemen opnieuw te behandelen, maar wel om de oprichting van de Compagnieën preciezer af te wegen tegenover de crisis van

Braziliaan F. A. Varnhagen, História das lutas com os Holandezes no Brazil desde 1624 a 1654 (Lissabon, 1872).

3. Cordova-Bello, Compañias Holandesas, 5, 24-26.

4. A. Levae, Recherches historiques sur le commerce des Belges aux Indes pendant le XVIIe siècle (Brussel, 1842) 78-80; A. de Haulevilie, Les aptitudes colonisatrices des Belges et la question coloniale en Belgique (Brussel, 1898) 28-29; J. Denucé, Afrika in de XVle eeuw en de handel van Antwerpen (Antwerpen, 1937) 83.

5. H. Pirenne, Histoire de Belgique (Brussel, 1927) IV, 417.

6. R. van Roosbroeck, ed., Geschiedenis van Vlaanderen (Brussel, 1940) V, 249-256.

7. J. van Dillen, Het oudste aandeelhoudersregister van de Kamer Amsterdam der Oost-Indische Compagnie ('s-Gravenhage, 1958); I. J. Brugmans, 'De Oost-Indische Compagnie en de welvaart in de republiek', Tijdschrift voor Geschiedenis, LXI (1948) 230. 
de Zuidnederlandse economie en te situeren binnen de verhoudingen tussen Noord en Zuid, kortom binnen de Tachtigjarige Oorlog en zijn economische implicaties.

De Belgische historici hebben zich weinig of niet ingelaten met de koloniale handel der Zuidelijke Nederlanden vóór de oprichting der Compagnieën. Wel werd de verhandeling van koloniale waren te Antwerpen als een der determinerende factoren in de bloei van de stad voldoende onderstreept, ja zelfs overschat ${ }^{8}$. De eigenlijke handel, die vanuit de Nederlanden tot in de koloniën zelf reikte, werd als onbelangrijk of als onmogelijk omwille van het Spaanse monopolie van de hand geschoven?.

Dit lijkt ons een vergissing. Deze koloniale handel verdient al evenzeer als de zestiende-eeuwse Amsterdamse handel in rekening gebracht te worden als background voor de Compagnieën. De omvang van de Zuidnederlandse handel op de koloniën in de eerste helft van de zeventiende eeuw hebben wij elders bepaald ${ }^{10}$. Welnu, die handel was toen minder een alternatief of een compensatie vanwege de Spaanse heersers voor de Compagniehandel dan wel de voortzetting en uitbloei van een reeds traditionele handel, die tot ver in de zestiende eeuw teruggaat. In welke mate deze koloniale handel der Nederlanders tot in de eerste helft der zestiende eeuw en zelfs voordien terug te vinden is, laten wij hier buiten bestek ${ }^{11}$. Feit is echter dat vooraleer de Opstand op het economische plan en meer bijzonderlijk in de koloniale handel begon door te werken er reeds een duidelijke deelname was der Nederlanders, uit zowat alle provincies, in zowel de Spaanse als de Portugese koloniale handel, die veel opener was dan tot nu toe algemeen aangenomen wordt ${ }^{12}$. Circa 1560 was Sevilla een der drukste handelscentra voor kooplieden uit Antwerpen, Brugge, Middelburg, Haarlem. Vanuit die stad werd door tientallen Nederlanders dank zij het Spaanse vlotensysteem druk handel gedreven met NieuwSpanje en het Zuidamerikaanse vasteland. Zij deden dat onder een schuilnaam, via Spaanse tussenpersonen of met de formule 'a pagar en las Indias', dwz.: betaling in Amerika door de perulero of facteur voor koopwaren die hij te Sevilla toevertrouwd kreeg door Nederlanders die daardoor dus in de gelegenheid waren

8. W. Brulez, 'Der Kolonialhandel und die Handelsblüte der Niederlande in der Mitte des 16. Jahrhunderts', Kölner Vorträge zur Sozial- und Wirtschaftsgeschichte, III (Keulen, 1969).

9. H. van der Wee situeert deze frustraties in zake de verhandel reeds in de zestiger jaren van de zestiende eeuw. H. van der Wee, 'De economie als factor bij het begin van de opstand in de Zuidelijke Nederlanden', Bijdragen en Mededelingen betreffende de Geschiedenis der Nederlanden, LXXXIII (1969) 24.

10. E. Stols, De Spaanse Brabanders of de handelsbetrekkingen der Zuidelijke Nederlanden met de Iberische Wereld, 1598-1648, (Verhandelingen van de Koninklijke Vlaamse Academie, Klasse der Letteren, jaargang XXXIII, no. 70: 2 dln; Brussel, 1971) I, 94-142.

11. J. A. van Houtte en E. Stols, 'Les Pays-Bas et la 'Méditerranée atlantique' au seizième siècle', Mélanges F. Braudel ( 2 dln; Toulouse, 1972) I. Wij willen elders terugkomen op deze handel op basis van documenten uit het Archivo de Indias te Sevilla.

12. A. Dominguez Ortiz, The Golden Age of Spain (Londen, 1971) 298-299; C. R. Boxer, The Portuguese Seaborne Empire, 1415-1825 (Londen, 1969) 61-62. 


\section{E. STOLS}

daar goederen of zilver te laten aankopen. Meerderen zijn er zelf heen getrokken of hebben er zich zelfs voor langere duur gevestigd. Dit gebeurde stiekem ofwel dankzij een door de koning verleende naturalisatie of licentie of nog door middel van een met de plaatselijke gouverneur gesloten composición of overeenkomst. Op een soortgelijke manier bestond er ook een drukke handel met Lissabon en van daaruit met de Portugese koloniën in Azië en Brazilië. Bedrijfeconomisch gezien was deze koloniale handel zeker mee met zijn tijd ${ }^{13}$.

$\mathrm{Nu}$ was deze koloniale handel onder het schut van het Spaans-Portugese koloniale systeem weer geen exclusiviteit voor de Nederlandse onderdanen van de Spaanse koning. Men treft er naast Hamburgers en cristãos novos ook kooplieden uit Rouen of Londen aan. Het was een internationale handel in de volle betekenis van het woord, waarin ten slotte de staatsonderdanigheid nog weinig of niet telde. Ook de religieuze verscheidenheid speelde daarbij geen grote rol. De Spaanse en Portugese Inquisities hadden weliswaar in dat heterodoxe koopliedenmilieu toegeslagen, maar dat gebeurde vooral in de vijftiger jaren. Nadien werden de processen veel zeldzamer, voornamelijk omdat de kooplieden op hun hoede geraakten en zich op het Iberisch schiereiland en in de koloniën als katholieken voordeden ofwel daar katholieke factors in hun plaats aanstelden. Nederlanders, of ze nu Rooms gebleven waren of aan de zijde van de Hervorming stonden, of zij nu met de Opstand naar het Noorden getrokken of in het Zuiden gebleven waren, dreven zonder schroom handel onder elkaar en betrokken daarin Engelsen, Hanzeaten en Portugezen. Tevergeefs zal men een strakke groepsvorming onder die kooplieden zoeken op basis van nationaliteit of van politieke en religieuze overtuigingen.

Het heet dat de maatregelen van Filips II tegen de Hollandse schepen in de Spaanse en Portugese havens, de bekende embargos, deze handel sterk gehinderd en onderbroken hebben en daardoor de Nederlandse kooplieden tot de directe koloniale handel en de stichting der Compagnieën hebben gedwongen. Dit is althans de klassieke verklaring voor de oprichting der Compagnieën. Zij werd door P. Blok geformuleerd - in antwoord op de opvatting van Preuss die hen eerder als product van de expansieve en krijgszuchtige geest der Verenigde Provinicën beschouwde - en sedertdien als het meest plausibel aanvaard ${ }^{14}$.

Er valt daarop aan te merken dat die embargos in feite niet zo uitzonderlijk in het tijdskader waren en zeker niet voor lange duur het handelsverkeer tussen het

13. E. Otte, 'Träger und Formen der wirtschaftlichen Erschliessung Lateinamerikas im 16. Jahrhundert', Jahrbuch für Geschichte von Staat und Wirtschaft Lateinamerikas, IV (1967) 226-266.

14. P. Blok, Geschiedenis van het Nederlandsche volk (Leiden, s.a.) II, 308, 309; G. Preuss, Philips II, die Niederländer und ihre erste Indiënfahrt (Breslau, 1911); W. J. van Hoboken, 'The Dutch West India Company: The Political Background of its Rise and Decline', in J. S. Bromley en E. H. Kossmann, ed., Britain and the Netherlands (Londen, 1960) 1,44-45; P. Chaunu, Conquête et exploitation des nouveaux mondes, Nouvelle Clio, XXVI bis (Parijs, 1969) 359-360; Boxer, Portuguese Seaborne Empire, 108-109. 
Noorden en het Iberisch schiereiland onderbroken hebben. Zij werden ongetwijfeld als politieke propaganda opgeschroefd en maken deel uit van de leyenda negra. Ook de uitwijzingsbevelen tegen vreemdelingen in de koloniën, die men voor die periode regelmatig terugvindt in de leyes de Indias, werden in feite niet stipt nageleefd $^{15}$. De Portugezen zullen later trouwens Filips II die mildheid verwijten: 'deixou respirar os Holandezes que pudera sogeitar a menos custa' ${ }^{16}$. Integendeel konden in die troebele tijd verscheidene Nederlanders, als de bekende Van Linschoten of de gebroeders De Coutre, naar Oost-Indië vanuit Lissabon vertrekken, terwijl te Sevilla anderen genaturaliseerd werden of zich naar Indias konden inschepen ${ }^{17}$. Nederlandse schippers bleven haast ongestoord naar Santo Domingo, Rio de Janeiro of Angola varen en legden onderweg rustig aan in de monding van de Taag of op de Canarische eilanden ${ }^{18}$. Nederlanders en Noorderlingen werden toen allerminst terzijde geschoven als in naam van de koning contracten voor koloniale waren gesloten moesten worden: de pepercontracten met Conrado Rott, met de Paris en met de Antwerpenaar Giovanni Baptista Rovelasca, het contract over brazielhout met de groep kooplieden rond João du Bois, Julien del Court en Hendrik Barendsz, het contract voor de Westafrikaanse handel met Jacome Fixer $^{19}$. Bovendien duurde het eigenlijk wel heel lang, niet minder dan tien jaar, vooraleer als reactie de eerste Compagnieën op den Oost tot stand kwamen en nog langer vooraleer de Oostindische Compagnie definitief van wal stak en zelfs nog tot 1621 vooraleer ook de handel met Amerika in compagnievorm georganiseerd werd. Er moet derhalve naar een meer genuanceerde en meer complexe verklaring voor de oprichting der Compagnieën gezocht worden.

Er werd ons inziens geen voldoende rekening gehouden met de innerlijke zwakheden van het Spaans-Portugese monopolie. Vooral het Portugese koloniale monopolie vertoonde reeds lang voor de opkomst van de Hollandse macht in OostIndië diepe scheuren. V. Magalhaes Godinho gewaagt van een grondige crisis, een

15. M. E. Rodriguez Vicente, 'Los extranjeros en el reino del Peru a fines del siglo XVI', Homenaje a Jaime Vicens Vives (Barcelona, 1967) II, 534-536.

16. M. T. Trigo Neto e Cova, 'O pensamento politico de Duarte Ribeiro de Macedo', Do tempo e da história, III (1970) 152.

17. Vida de Jacques de Coutre. - Biblioteca National, Madrid, manuscritos, 2780.

18. F. C. Wieder, Nederlandsche historisch-geografische documenten in Spanje (Leiden, 1915) 213-214; J. W. IJzerman, 'Amsterdamsche bevrachtingscontracten, 1591-1602, I, De vaart op Spanje en Portugal', Economisch-Historisch Jaarboek, XVII (1931) 185-187, 205, 210, 216, 226; E. Sluiter, 'Dutch-Spanish Rivalry in the Caribbean Area, 1594-1608', Hispanic American Historical Review, XXVIII (1948) 165-196.

19. H. Kellenbenz, 'Autour de 1600: Le commerce du poivre des Fugger et le marché international du poivre', Annales. Economies. Sociétés. Civilisations, XI (1956) 1-28; Stols, De Spaanse Brabanders, I, 107-108; H. Kellenbenz, 'Jacome Fixer', Portugiesische Forschungen der Görresgesellschaft, VIII (1968) 251-274. 
wending die zich reeds circa 1550 voordeed $^{20}$. De heropleving van de Venetiaanse specerijenhandel via de Ormuz-Aleppo-route in de tweede helft van de zestiende eeuw, het verlies op zee van de te grote kraken, het gebrek aan een degelijke bemanning en de stijgende moeilijkheden in Azië zelf waren er de symptomen van. De kooplieden die zich aan de pepercontracten waagden, hebben er meestal geen goede zaken mee gedaan. Ook het Sevillaanse monopolie voor de Amerikahandel beleefde reeds moeilijke dagen, zij het in mindere mate: gebrek aan scheepstonnage en -uitrusting, zware tarieven en toenemende bureaucratie, smokkel zowel te Cadiz en te Sanlúcar als in de Caribische Zee, groeiend aantal zeelieden en soldaten, die met hun kleine handel de markt bedierven ${ }^{21}$. Als bureaucratische instelling bleef dit monopolie overeind, maar daaraan beantwoordde minder en minder een echt commercieel monopolie in de verdeling en de prijsbepaling der koloniale waren en der goederen bestemd voor de koloniale afzetmarkt. De kooplieden die zich met hun firmaorganisatie op een degelijk monopolie ingericht hadden, moesten meer en meer ervaren dat kladders de prijzen bedierven en zowat overal koloniale waren op de markt wierpen. $\mathrm{Zij}$ werden geconfronteerd met het fenomeen van de afnemende rentabiliteit.

Erger nog kreeg deze gevestigde handel het te verduren van het toenemend aantal zeerovers, eerst de Engelse privateers, vooral sedert 1585, en mettertijd ook kapers uit Vlissingen, La Rochelle e.a. Het conquista-geweld, dat zo karakteristiek heet te zijn voor het begin van de Spaanse en de Portugese kolonisatie, luidde op een vergelijkbare manier ook de opkomst van de Engelse en Hollandse koloniale macht in. Op driejaar tijd, van 1589 tot 1591, werden door de Engelsen 236 schepen opgebracht, waarvan de meeste met koloniale waren geladen ${ }^{22}$. De slachtoffers daarbij waren niet alleen de Spaans-Portugese koninklijke schatkist, die zich van een bron van douane-inkomsten beroofd zag, maar ook zeer vele koopliedenbeurzen zowel te Lissabon, te Sevilla als te Amsterdam, Hamburg, Antwerpen en te Londen zelf. Onder de verliezers bij het uit Oost-Indië terugkerende Portugese schip, São Felipe, dat in 1587 door Engelsen genomen werd, bevonden zich de gebroeders Rodrigues d'Evora, een typisch internationale firma, die zowel te Antwerpen en te Lissabon als te Keulen en te Amsterdam gevestigd was ${ }^{23}$. Hetzelfde gold voor het verlies van de kraak Madre de Deus. Een veelzeggend geval is dat van de Fortuna, in maart 1595 bij Santo Domingo door de Engelse Rose Lion genomen en te

20. V. Magalhães-Godinho, L'économie de l'empire portugais aux XVe et XVIe siècles (Parijs, 1969).

21. H. en P. Chaunu, Séville et l'Atlantique, 1504-1650 (8 dln; Parijs, 1955-1959).

22. K. R. Andrews, Elizabethan Privateering. English Privateering during the Spanish War, 15851603 (Cambridge, 1964) 32, 243-273.

23. H. Kellenbenz, 'Die Rodrigues d'Evora in Köln', Portugiesische Forschungen der Görresgesellschaft, VI (1966) 281-282. 
Plymouth opgebracht ${ }^{24}$. Haar lading suiker en gember werd weldra bij de admiraliteit opgeëist door een groep kooplieden uit Amsterdam, Keulen en Hamburg, waaronder verscheidene Antwerpenaars, die beweerden dat zij het schip uit Arnenemuiden op Sanlúcar bevracht hadden en dat het van daaruit door John Aurikes, alias Juan Enriquez, en Egbert Vandermaten, beiden te Sevilla gevestigde Nederlanders, met een gedeeltelijk Nederlandse bemanning naar Santo Domingo gezonden werd. De kapers antwoordden daarop dat Enriquez de Spaanse naturalisatie bekomen had en de feitelijke eigenaar van de lading was, zodat de prooi hun toegewezen werd. De meest voorkomende prijs was de Brazilië-vaarder, die uit Bahia of Pernambuco met suiker en brazielhout naar Lissabon of Porto terugkeerde of rechtaan naar het Noorden liep. Tijdens de jaren 1589-1591 werden er negenenzestig de Engelse havens binnengebracht, zodat de suiker te Londen merkelijk goedkoper werd dan te Lissabon of te Bahia zelf ${ }^{25}$.

De kooplieden keken uit naar tussenkomst en bescherming van hogerhand. Filips II liet in 1594 toe dat de Hollandse hulken, met bestemming Brazilië, jaarlijks in twee vloten van twintig schepen samen zouden varen om zich beter te beschermen $^{26}$. De Duinkerkers konden ook als compensatie Engelse schepen opbrengen. Meer kon de Spaanse koning niet doen, gezien het gebrek aan schepen en de oorlogstoestand met Engeland en de opstandige Provincieën. De Hanzesteden wezen de Merchant Adventurers uit Duitsland als represaille voor het nemen van hun schepen uit de Braziliëvaart ${ }^{27}$.

Ook de Staten-Generaal ontvingen voortdurend verzoekschriften om tussenkomst bij Elizabeth voor de restitutie van die goederen. Onder de supplianten treft men kooplieden van de meest diverse pluimage aan: Reynier Pauw, Hans de Schot, Louis de le Becque en Gaspar Quinget uit Amsterdam, João du Bois en Jeronimo de Vadder uit Lissabon, Johan van der Veken uit Rotterdam, de Portugese Ximenes, de Vlaams-Hanzeatische Hulschers, Rocha's en Anselmo's en de Hellemans, zowel uit Zuid-Europa als uit het Noorden afkomstig ${ }^{28}$. Natuurlijk

24. K. R. Andrews, ed., English Privateering Voyages to the West Indies, 1588-1595, Hakluyt Society, Second Series, CXI (Londen, 1959) 338-365.

25. Boxer, Portuguese Seaborne Empire, 105.

26. S. Buarque de Holanda, ed., História Geralda Civilizacão Brasileira (Sao Paulo, 1963) I,166.

27. Andrews, Elizabethan Privateering, 233; H. Kellenbenz, 'Der Brasilienhandel der Hamburger 'Portugiesen' zu Ende des 16. und in der ersten Hälfte des 17. Jahrhunderts', Portugiesische Forschungen der Görresgesellschaft, I (1960) 316-334.

28. N. Japikse, ed., Resolutiën der Staten-Generaal van 1576 tot 1609, X, 1598-1599, RGP, Grote Serie, LXXI ('s-Gravenhage, 1930) 799, 808, 809; ibidem, XI, 1600-1601, RGP, Grote Serie, LXXXV ('s-Gravenhage, 1941) 113, 186, 326, 329, 339, 344, 345, 694; H. H. P. Rijperman, ed., ibidem, XII, 1602-1603, RGP, Grote Serie, XCII ('s-Gravenhage, 1950) 108, 288, 303, 603; ibidem, XIII, 1604-1606, RGP, Grote Serie, CI ('s-Gravenhage, 1957) 225-226, 502, 811; H. Ottsen, Journael van de reis naar Zuid-Amerika (1598-1601), J. W. IJzerman, ed. in Werken Linschoten-Vereniging, XVI ('s-Gravenhage, 1918) xxiv-xxvii; W. Brulez, Marchands flamands à Venise, I,1568-1605 (Brussel-Rome, 1965) 303, 304. 
werden deze kooplieden niet door één religieuze of politieke gerichtheid gebonden: wat hen samenhield was een internationale solidariteit op basis van familieverwantschap en wederzijdse belangen, van participatie- en correspondentie-ethiek ${ }^{29}$. Neteliger werd de bemiddeling voor de Staten-Generaal wanneer Hollandse en Zeeuwse kapers, zoals Paulus van Caerden en Broer Janszoon, in Brazilië suiker en zilverrealen in beslag namen uit Hollandse schepen, die tot deze internationale groep van kooplieden behoorden ${ }^{30}$. Hier was de situatie wezenlijk verschillend met de Engelse, want daar rechtvaardigden zich de privateers met het feit dat voor hen de gewone handel met Spanje en Portugal helemaal onderbroken was, terwijl dit voor de Nederlanders niet het geval was ${ }^{31}$. Voor wie moesten de Staten-Generaal hier partij kiezen?

De keuze was des te moeilijker omdat naast de regionale wedijver tussen Zeeland en Amsterdam, de religieuze tegenstellingen tussen Noord en Zuid en de oorlog met Spanje, ook zekere sociale conflicten van belang waren. Wat de Engelse zeerovers betreft stipt K. R. Andrews terecht aan: 'there was an element of democracy in privateering ${ }^{132}$. Hetzelfde geldt zeker ook voor heel wat uitrustingen uit Zeeuwse en Hollandse havens, waarin zeelieden, herbergiers, kleinere kooplieden deel hadden. De prijzen die binnengebracht werden, gingen meestal tegen weinig geld van de hand en lagen binnen het bereik van kleine kapitaalbezitters. Naast de tabak zijn waarschijnlijk sommige koloniale waren pas toen werkelijk in het volksverbruik doorgedrongen. Ook aan de andere kant binnen het Spaans-Portugese systeem kan men gewagen van een zekere volkse reactie, in die zin dat de bemanning op die schepen, of ze nu Portugees of gedeeltelijk Nederlands was, weinig of geen weerstand bood aan de kapers en zich liet opleiden wellicht in de hoop een deel in de buit op te strijken. Filips II maakte zich ongerust over deze gemakkelijke overgaven $^{33}$. Toen een Engelse privateer bij Tenerife een Portugees schip nam, was hij verwonderd dat er toch een schot viel, maar het kwam van een artillerist, 'beeing a drunken Fleming ${ }^{\prime 34}$. De oorzaak van die lakse houding lag minder in sympathie voor de Opstand dan in de bijzonder lage lonen en onregelmatige uitbetalingen op de Portugese schepen. De consul van de Duitse en Nederlandse natie te Lissabon, Conrado Rott, zag er een der voornaamste oorzaken in van de Portugese ver-

29. Stols, De Spaanse Brabanders, I, 257-276.

30. Rijperman, ed., Resolutiën Staten-Generaal, XIII, 226, 498, 505, 716, 807; Ottsen, Journael, 175, 176, 202, 203, 206; A. Tenenti, Naufrages, corsaires et assurances maritimes à Venise, 15921609 (Parijs, 1959) 434.

31. Andrews, Elizabethan Privateering, 221.

32. Ibidem, 234.

33. Ibidem, 207.

34. W. Foster, ed., The Voyages of Sir James Lancaster to Brazil and the East Indies, 1591-1603, Hakluyt Society, Second Series, LXXXV (Londen, 1940) 59,144. 
liezen $^{35}$. Voor de zeeman of de artillerist uit de Nederlanden die jaren lang dienst gedaan had op de Portugese schepen naar de Oost of naar Brazilië, of voor de factor die er de grote kooplieden vertegenwoordigd had, leek het uur aangebroken om zelf meer profijt te halen uit zijn opgedane ervaring.

Nochtans mag men deze tegenstelling tussen de oude handelsaristocratie en die opkomende meer volkse koloniale handelaars niet te scherp zien. Onder eerstgenoemde waren er meerderen, die mettertijd ook onder de reders voor rooftochten gingen figureren. Dit was ook het geval in Engeland ${ }^{36}$. Anderzijds had het volk in de havens er misschien baat bij, maar de gewone man in de nijverheidscentra moest wel ondervinden dat via deze rooftochten niet meer en eerder minder Hollandse textiel in de kolonies afzet vond dan via het Spaans-Portugese monopolie. In feite ging die democratisering zich weldra kristalliseren rond een groep van nieuwe rijken en ontstonden er vlug al even grote zo niet grotere koloniale fortuinen.

Problematisch werd daardoor ook de distributie der koloniale waren. Amsterdamse handelaars, die de erfenis van Antwerpen wilden overnemen, moesten constateren dat zowat overal grote hoeveelheden koloniale waren op de markt geworpen werden, en tegen zeer onregelmatige prijzen. In 1593 was er zoveel suiker te Londen, dat de Hollanders zich daar moesten gaan bevoorraden in plaats van in Brazilië en in Portugal ${ }^{37}$. Daarentegen stegen de prijzen van de specerijen bij de aankoop in Azië, omdat de nieuwgekomenen er zich te talrijk en te begerig als kopers aanboden. Enige controle op de prijzenbeweging moest dringend hersteld worden ten voordele van de koopliedengemeenschap.

Het was deze verwarde en conflictenrijke situatie die men door de oprichting van de Verenigde Oostindische Compagnie wilde verbeteren. Het octrooi voor een soortgelijke compagnie voor de handel met Amerika bleef nog jaren in de lucht hangen. De tegenstand van Oldenbarnevelt en zijn partijgangers daartegen is welbekend. Nog andere factoren bepaalden dit uitstel. Door de vrede tussen Spanje en Engeland, gesloten in 1604, verminderde de druk van de Engelse privateers op het Spaans-Portugese schepenverkeer met de Amerikaanse kolonies. Dit werd verder opnieuw begunstigd door de vredesonderhandelingen en tenslotte door het Bestand zelf. De vaart op Brazilië op Portugees-Nederlandse schepen in samenwerking met Portugese, Hamburgse en Zuidnederlandse kooplieden fleurde weer op. In Holland zelf gingen stemmen op om deze handel via Portugal, in het bijzonder dan over Viana en Porto, te verkiezen boven de vrijbuiterij en de con-

35. H. Kellenbenz, 'Le front hispano-portugais contre 1'Inde et le rôle d'une agence de renseignements au service de marchands allemands et flamands', Studia, XI (1963) 283; Boxer, Portuguese Seaborne Empire, 214.

36. Andrews, Elizabethan Privateering, 100.

37. Ibidem, 208. 


\section{E. STOLS}

fiscaties $^{38}$. Die vreedzame handel via Portugal was lonender omdat de handelsbalans in de uitwisseling van Braziliaanse suiker en brazielhout tegen Hollandse textiel en kramerijen in het nadeel van de Nederlanden uitviel en men dus beter dit deficit aanvulde door op de heenreis wijnen, olie en andere landbouwproducten op het Iberisch Schiereiland voor Brazilië te gaan laden. Niettemin werden er toch reeds onder het Bestand enkele krijgshaftige expedities, bijvoorbeeld die van Van Spilbergen en Le Maire, naar Amerika gestuurd en tenslotte liep ook de Westindische Compagnie van stapel.

De oprichting van deze Compagnieën heeft daarom minder de betekenis van een vernieuwing, bedrijfeconomisch gezien, of van het startsein voor de Hollandse koloniale handel dan wel vooral van de staatstussenkomst in de handel en in het economisch leven. Met de Compagnieën werd een belangrijke stap gezet naar regeling van het handelsleven en politiek gebruik van de economi ${ }^{39}$. Men zou hier als 't ware van een nationalisatie 'avant la lettre' kunnen gewagen. Een zeer internationaal gekleurde koloniale handel werd onder een nationale vlag en in een nieuw monopolie gedwongen. Een kosmopolitische koopliedengemeenschap, die te gemakkelijk verhuisde, kreeg een nieuwe nationaliteit. Het zeevarend volk dat toch heel weinig bindingen kende, werd gemobiliseerd voor de natie. Men ging zelfs heel wat ervaren stuurlieden en piloten op de vijand terugwinnen, hetzij door hen uit te wisselen tegen Spaanse en Portugese gevangenen, hetzij door hen te 'bevrijden' op vijandelijk terrein. Het werd een echte scheiding der wateren. Andere specifiek politieke doeleinden waren het vermijden van verdere conflicten met neutralen als de Hanzesteden en de Venetiaanse republiek en ook het herstel binnen de Republiek van een rechtsleven, een rechtsstaat inzake maritieme aangelegenheden. Ondanks de ogenschijnlijke democratisering die de gehele natie bij de koloniale handel moest betrekken, hebben de Compagnieën door hun politieke macht, door het herstel van een monopolie en door de revalorisatie der prijzen in feite de koopliedenstand gerustgesteld en voor zich gewonnen. Dit gebeurde echter niet zonder moeilijkheden noch tegenstand, want sommige kooplieden zochten zich eraan te onttrekken of gingen elders hun compagnieën oprichten.

Onverholen was ook de bedoeling om de Spaanse vijand te treffen in zijn koloniën en op diens geldmiddelen, het Amerikaanse zilver, beslag te leggen ten bate van de eigen krijgsverrichtingen en de eigen handel met Azië. Deze nationalisatie bedoelde echter niet alleen Spanje maar evenzeer de Spaanse partij in het Zuiden, de Spaanse

38. Ottsen, ed., 'Deductie vervaetende den oorspronck ende progres van de vaert ende handel op Brasil', Journael, 98-106.

39. Zie ook J. C. Riemersma, 'Government Influence on Company Organization in Holland and England (1550-1650)', The Journal of Economie History, Supplemental Issue, X (1950) 31-39; L. Dermigny, 'L'organisation et le rôle des compagnies', in M. Mollat, ed., Sociétés et compagnies de commerce en Oriënt et dans l'océan Indien, Actes du 8ième colloque international d'histoire maritime (Parijs, 1970) 443-451. 
Nederlanden, van hun koloniale handel en economische kracht te beroven. Voor die kooplieden die nog via Lissabon en Sevilla verkozen te handelen, moest het duidelijk worden dat de koloniale handel nog alleen binnen de onafhankelijke Nederlanden mogelijk zou zijn en dat zij hun kapitalen beter daar konden plaatsen. Hier ziet men reeds de politiek die later, met de Vrede van Munster leidde tot de definitieve sluiting van de Schelde en de handhaving van de koloniale status quo en die zich ook daarna tegen elke koloniale onderneming van het Zuiden verzette, zoals duidelijk bleek uit de episode van de Oostendse Compagnie.

Deze bedoeling was in den beginne misschien niet zo expliciet aanwezig. Toch wijzen heel wat feiten in die richting. Jacques de Coutre uit Brugge was via Portugal in de Aziatische handel terechtgekomen. Juist zoals Van Linschoten, maar hij was er gebleven. Toen hij te Pattani een jonk op Malacca geladen had, zag hij dat zijn schip moedwillig tot zinken gebracht werd door de vloot van Jacques van Heemskercken, nadat deze tevergeefs geprobeerd had hem voor de Hollandse scheepvaart aan te werven ${ }^{40}$. De mannen van Joris van Spilbergen, die te Sao Vicente in Brazihë aan land kwamen, staken er het suikerhuis en de bezittingen der aan de Spaanse koning trouw gebleven Schetz in brand ${ }^{41}$. Zij wisten nochtans dat het 'ghebouwt was van' een seecker geslacht van Antwerpen ghenaemt de Schotsen'. In een soortgelijk incident had ook de engenho van Duarte Hulscher op het eiland Itaparica in de baai van Salvador de Todos os Santos het voordien moeten ontgelden van een Hollandse vloot. Nog te Bahia, bij de aanslag van Piet Heyn in 1627 op een aantal Hamburgse schepen, verloren meerdere te Lissabon gevestigde Vlamingen veel goederen ${ }^{42}$. Na de verovering van Pernambuco werd de engenho São Marcos te Marapatagiba die aan de loyaal gebleven Antwerpenaar Gaspar de Mere toebehoorde, geconfisqueerd.

Ook indirect hadden de Hollandse ondernemingen een negatieve weerslag op de koloniale handel der Zuidnederlanders. Sedert het voorbeeld van Van Linschoten en Houtman golden zij in de ogen van de Spaanse administratie als een gevaarlijke vijfde colonne die uit de koloniën verwijderd moest worden, wilde men de Hollandse penetratie stopzetten. Een Brugs jezuïet schreef het kernachtig vanuit Mexico in 1617: 'Difficilis imposterum Flandris aditus in Indiam videtur futurus, et hoc traditoribus Hollandis ${ }^{43}$.

Wat reeds door de missionarissen gevreesd werd gold des te meer voor de kooplieden. Zoals gezegd had Filips II ondanks zijn herhaaldelijk uitgedrukte ongerustheid geen radikale maatregelen werkelijk laten uitvoeren. Opnieuw werd er onder

40. Vida de Jacques de Coutre. - Biblioteca National, Madrid, manuscritos, 2780, f. 64 vo-72.

41. J. Warnsinck, ed., De reis om de wereld van Joris van Spilbergen, 1614-1617, Werken Linschoten-Vereniging, XLVII ('s-Gravenhage, 1943) 1,15-16.

42. Boxer, Portuguese Seaborne Empire, 40.

43. J. Andriessen, De Jezuïeten en het samenhorigheidsbesef der Nederlanden, 1585-1648 (Antwerpen, 1957) 46. 
Filips III begonnen met een systematische navraag bij de gouverneurs naar Vlamingen die de Hollanders zouden kunnen behulpzaam zijn. Ditmaal werd het menens en dit zeker niet zonder verband met de Hollandse veroveringen. Enkelen werden toen inderdaad uit Brazilië gewezen of mochten er uit Lissabon niet meer terugkeren. Een Manuel van Dale of een Gaspar de Mere slaagden er nochtans in zich opnieuw naar Brazilië in te schepen, terwijl anderen er rustig gebleven waren uit hoofde van hun lang verblijf, huwelijk met een Portugese, en bezittin$\mathrm{gen}^{44}$. Dergelijke uitwijzingsbevelen werden ook reeds in de eerste regeringsjaren van Filips III naar Goa gestuurd. Het duurde echter tot 1616 vooraleer de Bruggelingen Joseph en Jacques de Coutre werkelijk last kregen omwille van hun vermeende correspondentie met de Hollanders ${ }^{45}$. Zij beweerden nochtans dat zij de koning altijd over het doen en laten der Hollanders ingelicht hadden. Slechts enkele dagen zaten zij er gevangen; zij konden hun handel voortzetten. De Duitser Fernando Cron, die er correspondeerde voor Zuidnederlandse kooplieden uit Lissabon en Venetië, kende dezelfde moeilijkheden ${ }^{46}$. Omdat hij de koning geld voorgeschoten had voor de verdediging tegen de Hollanders, kwam ook hij weer vrij. Uiteindelijk werden zowel Cron als de De Coutre's in 1623 op de kraken naar Portugal gezet en werd aldus een einde gemaakt aan de Zuidnederlandse kolonie te Goa. Eenmaal terug op het Iberisch Schiereiland verwierven zij er opnieuw de koninklijke gunst en Jacques de Coutre gaf zelfs in verscheidene memorialen adviezen over de beste wijze waarop de Hollanders bestreden konden worden.

In Spaans-Amerika waren het hoofdzakelijk Hollandse zeelieden, doorgedrongen via Buenos Aires of aan wal gezet op de Westkust, die gevat werden en naar Sevilla overgebracht. Het net van Vlaamse kooplieden dat zich van Sevilla tot Mexico en Lima uitstrekte, bleef nagenoeg onaangeroerd. Alleen circa 1605 waren er moeilijkheden in de Andalusische havens, toen gedreigd werd de Hollanders en de Vlamingen die in het Noorden verwanten hadden, landinwaarts te deporteren. Met het Bestand werden deze incidenten gauw vergeten en van toen af nam het aantal naturalisaties en licenties om met Indias te handelen sterk toe.

In de Zuidelijke Nederlanden zelf werd in de winter van 1600-1601 te Antwerpen een onderzoek ingesteld naar de kooplieden die in de Hollandse ondernemingen geïnvesteerd hadden. Er werd een gezamenlijke boete van 600.000 dukaten opgelegd. De verleiding bleef echter groot om in te schrijven op de registers van de OIC en later van de WIC en verscheidene kooplieden zullen dit via hun Hollandse correspondenten ook gedaan hebben. Een zondebok werd gevonden in de persoon van

44. Stols, De Spaanse Brabanders, I, 94-142.

45. H. Fitzler, 'Der Anteil der Deutschen an der Kolonialpolitik Philipps II. von Spanien in Asien' ,Vierteljahrschrift für Sozial- und Wirtschaftsgeschichte, XXVIII (1935) 278-279; H. Kellenbenz, 'Le front hispano-portugais', 277; British Museum, Egertoniana, 1131, f. 45,47-50.

46. Vida de Jacques de Coutre. - Biblioteca Nacional, Madrid, manuscritos, 2780. 
Hendrik Hoens, een der rijkste Antwerpse zakenlieden, die gevangen gezet en zwaar beboet werd en wiens zaak tot in de Madrileense raden besproken werd. Nog in 1645 meende de Antwerpse koopman Crisostomo van Immerseel dat er verschillende stadgenoten betrokken waren in de Hollandse verliezen in Brazilië. Deze Zuidnederlandse medewerking met de Hollandse Compagnieën beperkte zich echter niet tot het verstrekken van informatie en tot intekeningen op de registers. Zuidnederlandse kooplieden bemiddelden vooral in de levering van zilverrealen, die zo broodnodig waren in de Aziatische handel. Zij werden ook aansprakelijk gesteld voor het binnenbrengen van peper in Spanje en Portugal, die via Amsterdam uit Oost-Indië kwam en de Portugese peper in eigen huis gevaarlijke concurrentie aandeed. Tenslotte was het mogelijk dat er Zuidnederlandse produkten, textiel, metaalwaren en kunstvoorwerpen, op de Compagniesschepen naar de koloniën geladen werden.

Nochtans werd deze medewerking met de Hollandse Compagnieën in de Zuidelijke Nederlanden niet onverdeeld gunstig beoordeeld. Integendeel, er kwam van verschillende zijden een scherpe reactie. Het was via de Zuidelijke Nederlanden en via Vlamingen en Hanzeaten op het Iberisch Schiereiland dat de Madrileense bestuurskringen het regelmatigst en uitvoerigst op de hoogte gebracht werden van de vorderingen in de Compagnie-organisatie en van de verschillende expedities. Een bonte groep van ambitieuze edellieden zoals Gabriel de Roye, van beroepsspionnen als de Antwerpse Portugees Manuel Soeiro, van intrigante geestelijken als Fray Martin de San Espiritu of de jezuiet Antonio Colazo, sloeg daar munt uit om de koning van hun ijver, bekwaamheid en trouw te overtuigen en een of andere beloning in de wacht te slepen ${ }^{47}$. Verrassender was de aanwezigheid van schippers en kapiteins onder die aanbrengers: Cornielis Guillermo, schipper op de Santiago uit Amsterdam, die te Sevilla in 1605 zijn verzoeningsbrief, afgeleverd vanwege Aartshertog Albrecht, kracht bijzette door copieuze inlichtingen te leveren over de afvaart van Hollandse schepen naar Oost-Indië ${ }^{48}$; of Melchior vande Kerckhove, geboren te Palma op de Canarische Eilanden, die tevoren verschillende schepen uit Middelburg naar Amerika gebracht had en die in 1616 voorstellen deed om de Hollandse koloniale handel te ruïneren ${ }^{49}$. Blijkbaar vertegenwoordigden zij die schippers, die liever individueel voor eigen rekening dan in compagniesverband uitvoeren en de vaart op Spanje en de eilanden voordeliger achtten dan de vaart op den verre.

47. M. van Durme, Les Archives générales de Simancas et l'histoire de la Belgique (Xle-XIXe siècles), Commission Royale d'Histoire (3 dln; Brussel, 1964-1968) I, 553, 585, II, 583-585, 589, 595-596, 600, III, 541, 599.

48. J. Gentil da Silva, Alguns elementos para a historia do comercio da India de Portugal existentes na Biblioteca Nacional de Madrid (Lissabon, 1950) 62-64.

49. Van Durme, Archives, I, 596; Wieder, Nederlandsche documenten, 213-214. 


\section{E. STOLS}

Er waren echter ook kooplieden die tegen de Compagnie partij durfden kiezen of althans zich aldus voordeden: de voorgenoemde Fernando Cron en de De Coutre's; een Andres van Gessel ook, een aanzienlijk Antwerps koopman, die voordien te Sevilla geresideerd had ${ }^{50}$. Het is begrijpelijk dat een Baltasar Schauvlieger, leverancier van scheepsmateriaal voor de Portugese vloten te Lissabon, de Hollandse Compagnie liever zag verdwijnen ${ }^{51}$. Hendrik Snel die te Porto in de suikerhandel stond, briefde de rol van sommige cristãos novos in de aanval van de Westindische Compagnie op Brazilië over ${ }^{52}$.

Deze berichtgevers en memorialisten onderstreepten meestal de door de Hollanders geleden verliezen, het gebrek aan geld en de ontevredenheid bij het volk ${ }^{53}$. Zij waren dan ook overtuigd van de kwetsbaarheid van de Hollandse Compagniehandel en verzonnen verschillende taktieken om hem te kelderen ten voordele van de Zuidelijke Nederlanden. Sommigen dachten aan economische en financiële maatregelen waardoor de Spaanse kroon de Hollandse ondernemingen te gronde kon richten. Conrado Rott stelde een tegenoffensief voor door de reorganisatie van de Portugese vaart op Oost-Indië: betere salarissen voor het scheepsvolk, stipte uitbetalingen door de kroon voor de levering van scheepsmateriaal, financiering der vloten en kapitaalwerving door middel van hoge rentevoeten, controle te Lissabon door vertegenwoordigers der Italiaanse en der Duits-Vlaamse naties, die daarom nog niet zelf tot de koloniën moesten toegelaten worden ${ }^{54}$. Zonder het nadrukkelijk zo te formuleren beoogde hij aldus te Lissabon een compagnie naar Hollands model op te richten. Rott's opvolger als consul, de Hanzeaat Johann Kampferbeck, wilde het succes van de Hollandse peperhandel breken door de Portugese peperverdeling toe te vertrouwen aan de Hanzesteden, die in ruil zouden instaan voor de uitrusting der schepen te Lissabon ${ }^{55}$. Dit betekende de heroprichting van de vroegere Portugese feitoria, nu niet meer te Antwerpen maar te Hamburg. Spitsvondiger maar haast niet te realiseren waren de voorstellen van een niet te identificeren memorialist die de hele situatie weer ten voordele van de Spaanse koning wilde omkeren door de Hollanders het zilver voor hun Aziatische handel te ontnemen. Dit kon volgens hem gebeuren door de waarde van het zilver in de Zuidelijke Nederlanden met $50 \%$ te vermeerderen, wat een ongunstig effect op de Amsterdamse peperprijs zou hebben, en anderzijds de prijs van de Portugese

50. Van Durme, Archives, II, 601.

51. Ibidem, III, 541.

52. British Museum, Egertoniana, 1131, f. 275.

53. Scribani bijvoorbeeld raamde de verliezen in de West-Indiëvaart op 10 miljoen gulden. L. Brouwers, Carolus Scribani S.J., 1561-1629. Een groot man van de contra-reformatie in de Nederlanden (Antwerpen, 1961) 486. Zie daarover ook Manuel Soeiro bij Van Durme, Archives, II, 615, 621-622; en Manuel Lopes Pereira in Archivo General de Simancas, estado, 2847.

54. Kellenbenz, 'Le front hispano-portugais', 263-264, 281-284.

55. Idem, 'Autour de 1600', 24-26. 
peper met $20 \%$ te verlagen, waardoor het goedkoper zou uitvallen in het Zuiden peper te kopen ${ }^{56}$.

Een andere methode was de Hollandse Compagnieën te infiltreren en eventueel naar het Zuiden over te brengen. Zowel scheepskapiteins als kooplieden werd gevraagd naar het Zuiden over te lopen. Men probeerde het bij Joris van Spilbergen, bij Jacques le Maire en bij verschillende piloten die een nieuwe weg via de Stille Oceaan zouden gevonden hebben ${ }^{57}$. Zonder succes echter. Hollandse kooplieden werden benaderd door Fray Martin de San Espiritu die bij hen de opheffing van de Compagnie bepleitte ${ }^{58}$. In dezelfde zin onderhandelde circa 1611 Jan Snel, een te Lissabon gevestigde Vlaming, met Hollandse kooplieden op de Antwerpse beurs ${ }^{59}$. Slechts één naam van dezen is ons bekend: het ging om Cornelis Matelief die voorheen een expeditie naar de Oost geleid had.

Gevaarlijker werden de infiltraties in de Westindische Compagnie. De spil daarvan lag te Viana en Porto bij kooplieden, hoofdzakelijk cristãos novos en Vlamingen, die met spijt constateerden dat hun rol van middenman in de suikerhandel met Holland sedert de inname van Pernambuco overbodig was geworden. Bovendien hadden zij blijkbaar verliezen geleden bij de vernieling of confiscatie van engenhos of bij het stilleggen der produktie ${ }^{60}$. Het komplot lekte uit en een zekere Leendert van Lom werd aangehouden, onthoofd en gevierendeeld ${ }^{61}$. Welnu, deze Van Lom vinden we omstreeks 1624 terug te Viana en blijkbaar was hij ook verwant met Jacques en Mathias van Lom die te Porto handel dreven. Onder zijn medeplichtigen werden Gaspar Domingo Rego en Roque de Barros vermeld, bekende suikerexporteurs uit Viana. Kort tevoren stond ook een Adriaan Verdonck onder verdenking van verraad en werd hij tijdelijk gevangen gehouden ${ }^{62}$. Ook hij was geen onbekende in het milieu van Vlaamse kooplieden die uit Lissabon op Brazilië handel dreven. Tijdens het Bestand was hij te Lissabon en zijn reizen naar Pernambuco stelden hem in staat de Hollanders een goed rapport over die streken in handen te spelen. Argwaan verwekte ook de brief van de Antwerpenaar Gaspar de Mere, die door de Westindische Compagnie onderschept werd. Duister is het geval van Adriaan van der Dussen, die in 1623 als 'Hollands vluchteling' inlichtingen verstrekte aan de Spaanse autoriteiten maar niettemin een rol speelde in de

56. Gentil da Silva, Alguns elementos, 66-67.

57. Van Durme, Archives, II, 19, 591, 593, 594, 596, 599.

58. Ibidem, 238, 573.

59. Wieder, Nederlandsche documenten, 213, 214.

$>$

60. M. Buescu, 'Invasão holandesa: perdas da economia açucareira', Verbum, XXV (1968) 397408 .

61. J. de Laet, Iaerlijck Verhael van de verrichtinghen der Geoctroyeerde West-indische CompagnieS. P. L. Honoré Naber, ed., Werken Linschoten-Vereniging, XXXIV ('s-Gravenhage, 1931, 1937) III, 104,107,132; Stols, De Spaanse Brabanders, 139.

62. Ibidem, II, 151. 


\section{E. STOLS}

Westindische Compagnie ${ }^{63}$. Een dubbel agent of iemand die op twee paarden wedde?

Tenslotte was er de groep die de Hollandse Compagniehandel zocht concurrentie aan te doen en te vernietigen door in de Zuidelijke Nederlanden zelf dergelijke koloniale compagnieën op te richten. Het eerst bekende voorstel dateerde van voor het Bestand en kwam van een advokaat, Thomas van Meerbeek, en van een gewezen stuurman op Hollandse schepen, Adriaan Adriaensen Brauwer. Zij wilden een Westindische Compagnie oprichten in het bijzonder voor de tabakhandel ${ }^{64}$. Enkele schepen zouden uit Duinkerke naar Trinidad, Cuba, Santo Domingo en Cumana afvaren en er Nederlandse produkten inruilen tegen huiden, verfstoffen en tabak. Zilver, goud en parels zouden aan de Spanjaarden voorbehouden blijven. Zij verwachtten alleen van de tabakhandel reeds een jaarlijkse opbrengst van een miljoen gulden. Daarmee meenden zij de Hollanders te vervangen, die sedert 1606 door de Spanjaarden uit de smokkelcentra van de Venezolaanse kust geweerd werden. Een dergelijk voorstel druiste natuurlijk in tegen het artikel van de Akte van Afstand van Filips II aan de Aartshertogen, waarbij hun onderdanen zich van de rechtstreekse handel met de Spaans-Portugese koloniën moesten onthouden.

Toch stelde de Aartshertog zich in 1613 achter een gewijzigd voorstel dat hij door de graaf van Solre te Madrid liet bepleiten ${ }^{65}$. Men zou zich nu beperken tot de vaart op de minder door de Spanjaarden bediende noordoostelijke kust van het Zuidamerikaanse vasteland, het huidige Venezuela en de eilanden Trinidad en Tobago. De Spaanse Consejo de Indias adviseerde negatief daarover wegens de gevaren voor de geloofszuiverheid in Amerika en een mogelijke heropleving van smokkelcentra. Wel werd de koning bereid gevonden Albrecht voor de duur van drie jaren drie schepen te laten zenden. Zij moesten zich op de heenreis ongeladen te Sevilla melden voor het register en op de terugreis opnieuw voor het betalen der rechten. Albrecht mocht er zijn persoonlijke factor aanstellen. Men kan alleen betreuren dat daar van Zuidnederlandse zijde niet op ingegaan werd want er stond een poort op een kiertje open voor eventuele verdere toegevingen.

In de jaren 1623-1624 kwamen dergelijke voorstellen opnieuw op tafel. Een plan om Spaans-Vlaamse handelscompagnieën op te richten stamde van Augustinus Bredimus, zoon van een Triers senator, die de functie van tolk bij de Duits-Vlaamse natie te Lissabon beoogde ${ }^{66}$. Meer aandacht besteedden de koninklijke raadgevers aan de memorialen van Francisco de Retama, burger van Jérez de la Frontera en economist in de dop, die zelf blijkbaar het Noorden bezocht had, en van Manuel

63. Van Durme, Archives, II, 31.

64. Stols, De Spaanse Brabanders, 111-113.

65. Van Durme, Archives, II, 583-584.

66. Ook hij is een goed voorbeeld van die al te ingenieuze memorialisten. Hij dacht er zelfs aan zo maar de Rijn af te leiden om de Hollandse handel te ruïneren. Ibidem, II, 29, III, 459. 
Lopes Pereira. Beiden wilden in de Zuidelijke Nederlanden compagnieën laten oprichten voor de handel met Oost-Indië ${ }^{67}$. Retama zag het als de enige oplossing om te concurreren met de Hollandse peperprijzen. Het kapitaal zou bijeengebracht worden door de kooplieden van het Zuiden die volgens hem tot dan toe bij gebrek aan andere handel wel verplicht geweest waren in het Noorden te investeren, maar ook door katholieke kooplieden in het Noorden die uit trouw aan de koning nog niet hadden willen deelnemen in de Hollandse Compagnieën. Pereira van zijn kant wilde de Zuid-Nederlanders vrij spel doen geven alleen op Ceylon en in de Indonesische Archipel met uitsluiting van de havens op het Indische vasteland, die aan de Portugezen voorbehouden bleven. Het octrooi zou voorlopig voor tien jaar lopen, met eventuele verlenging ofwel desnoods afschaffing indien de Portugezen ondertussen weer hun vroegere macht hadden kunnen herstellen. Het nodige zilver zouden de Zuid-Nederlanders op de heenreis te Lissabon innemen en in ruil daarvoor de asientos te Antwerpen uitbetalen. De junta del comercio antwoordde op 13 maart 1624 dat de koloniale handel om strategische redenen moest verboden blijven voor de Hollanders en men niet kon toelaten dat hun kapitalen in Zuidnederlandse compagnieën een toevlucht zouden vinden. Wel mochten de Vlamingen te Lissabon zelf een compagnie oprichten. Pas in 1640 gaf Filips IV de handel op Oost-Indië voor zijn Zuidnederlandse onderdanen vrij, maar weinige maanden later verloor deze beslissing door het herstel van een onafhankelijk Portugal haar betekenis.

Wat Amerika betrof kwam een dergelijke toelating er nooit. Nochtans moet hier gewezen worden op de oprichting van het Almirantazgo in 1624, die ten dele wel op de Hollandse Compagnieën geïnspireerd was ${ }^{68}$. Het Almirantazgo moest op geprivilegieerde wijze de handel regelen tussen Sevilla en de Andalusische havens enerzijds en de Zuidelijke Nederlanden en de Hanzesteden anderzijds. Deze compagnie had dus in se geen bevoegdheid voor de handel met de koloniën, maar aan verschillende stichters en kapitaalinbrengers werden naturalisaties en licenties verleend om vanuit Sevilla met Indias te handelen. Dit hield dus toch een belangrijke inbreuk op het Spaanse monopolie in, die tot verdere toegevingen kon geleid hebben. Het Almirantazgo ging echter de weg op van de kaperij die meer onmiddellijke resultaten opleverde.

Nog herhaaldelijk zocht men in de Zuidelijke Nederlanden het Hollandse voorbeeld na te volgen. In 1632 drongen de' Staten er bij Filips IV op aan te Oostende een compagnie op te richten ${ }^{69}$. Er was ook in de vijftiger jaren sprake van een Vlaamse kolonisatie op Santo Domingo. In 1661-1662 kwamen er opnieuw voor-

67. Archivo General de Simancas, estado, 2847; Van Durme, Archives, II, 597, 614, III, 525.

68. Stols, De Spaanse Brabanders, 14-24.

69. M. Gachard, ed., Actes des Etats généraux de 1632 (2 dln; Brussel, 1853) II, 214, 230, 235, $239,240,247,446$. 


\section{E. STOLS}

stellen, ditmaal van Brugse kooplieden, om schepen naar Amerika te sturen ${ }^{70}$. De pogingen onder Maximiliaan Emanuel zijn bekend ${ }^{71}$. Pas na de opheffing van de Spaanse heerschappij werd echter een ernstig begin gemaakt met de Compagniehandel vanuit Oostende naar Oost-Indië, maar waarbij ook de Braziliaanse kust niet uit het oog verloren werd ${ }^{72}$.

Het uitblijven van deze Compagniehandel in de Zuidelijke Nederlanden zal men natuurlijk aan de onwillige houding van het Spaanse bestuur toeschrijven. Men moet echter rekening houden met de voorgestelde toegevingen en met het Almirantazgo, als een soort verlengstuk van het Sevillaanse monopolie in de richting van Noord-Europa. Het was ook normaal dat Spanje, toen reeds in het defensief, zich meer inspande om zijn gevestigde handelsinstellingen te verdedigen en te ontwikkelen dan om nieuwe wegen in te slaan.

Ook de houding van de Zuidnederlandse kooplieden moet in de beschouwing betrokken worden. Een goed deel van deze mensen die behoorden tot wat als het type van een gekoloniseerde burgerij mag gelden, wilde in het buitenland investeren. Zij keken daarbij echter niet alleen uit naar de Hollandse Compagnieën maar ook naar de Franse, Zweedse en Deense initiatieven. Anderzijds hadden zij ruimschoots genoeg aan de koloniale handel die vanuit Sevilla en Lissabon nog met grote faciliteiten en vooral met kleinere kosten kon gedreven worden. De grote afzetmarkten voor de Vlaamse textiel en kant, kunst- en boekenuitvoer bleven de gehele zeventiende eeuw door nog binnen het Sevillaanse en later Caditaanse monopolie. Daarbij vergeleken betekenden de mogelijkheden op de door Fransen en Engelsen bezette Caribische eilanden en in de Hollandse nederzettingen van Suriname heel weinig. Bovendien kon daar met profijt de handel in Andalusische landbouwprodukten aan gekoppeld worden en was het mogelijk daarin te investeren. Indien bepaalde handelstakken als gevolg van de Hollandse veroveringen uitvielen, dan was dit soms alleen maar tijdelijk, zoals voor de Braziliaanse suikerhandel, of er kon naar gedeeltelijke compensatie uitgezien worden, zoals de opkomende diamanthandel van Antwerpen voor de weggevallen peperhandel. Dat er in deze koloniale handel kleinere bedragen van doen waren met minder kosten had ook tot gevolg dat meer geld kon worden vrijgemaakt voor andere sectoren zoals de aankoop van landgoederen, terwijl ook kleinere kooplieden gemakkelijker toegang kregen tot de koloniale handel. Dit gaf ongetwijfeld een eigen karakter aan de sociale mobiliteit in de Zuidelijke Nederlanden, die blijkbaar^niet onderdeed voor de democratisering die de Compagnieën in het Noorden met zich mee brachten. Wel is de gewone man daarbuiten gebleven en vinden wij, tegenover de Hollandse Jan Compagnie, alleen enkele soldaten en meiden, die voor hun dienst naar Spanje trokken.

70. Archivo General de Simancas, estado, 2272,10 en 4010, 3; Van Durme, Archives, II, 535.

71. R. de Schryver, 'Uit de voorgeschiedenis van de Oostendse Kompagnie', Handelingen van de Koninklijke Commissie voor Geschiedenis, CXXXVII (1966) 143-159.

72. E. Stols, 'A Companhia de Ostende e os portos brasileiros', Estudos Históricos, V (1966) 8295. 


\section{Justus Lipsius' levenskeuze: het irenisme}

\section{J. KLUYSKENS}

Justus Lipsius is steeds een omstreden figuur geweest: de veelzijdige activiteiten van de Zuidnederlandse humanist werden vaak uiteenlopend beoordeeld. In de achttiende eeuw zag P. Burman in hem niet minder dan een huichelaar, die met hart en ziel immer traditioneel rooms was gebleven, doch zich bij de lutheranen te Jena voor luthers, bij de calvinisten te Leiden voor calvinist liet doorgaan ${ }^{1}$. Een eeuw later beschouwde ook Ch. Nisard Lipsius als een onbetrouwbaar acteur die met geslepen behendigheid aan de buitenlandse universiteiten de schijn kon wekken de gangbare christelijke confessie te belijden, maar feitelijk steeds kortzichtig papist gebleven was ${ }^{2}$. Volgens G. H. M. Delprat veranderde Lipsius louter uit eerzucht van belijdenis en stapte hij, zijn universiteitsstad Leiden verlatend, naar de roomsen over in de overtuiging dat voor de voortzetting van zijn werk de kansen in het katholieke Zuiden beter waren ${ }^{3}$. H. T. Oberman meent dat Lipsius ongetwijfeld de Verenigde Provincies zekere diensten bewezen heeft, doch door zijn grenzeloze lafheid van karakter elke dankbaarheid onwaardig is ${ }^{4}$. Naar H. van Crombruggen oordeelde, verviel Lipsius van het ene uiterste in het andere: van uitwijkeling werd hij verdediger van de ultra-katholieken, die zijn ballingschap hadden veroorzaakt ${ }^{5}$. G. Oestreich is eveneens de mening toegedaan dat Lipsius een onstandvastige natuur was, die zijn onrust in zijn autobiografie heeft verbloemd. Hierin immers bracht hij een leven van een stille geleerde in beeld, die steeds de vurigste wens had gekoesterd naar zijn vaderland terug te keren ${ }^{6}$.

In een boeiend referaat betoogde H. F. Bouchery echter, dat in zake geloofsleer

1. P. Burman, Sylloge epistolarum a viris illustribus scriptarum (Leiden, 1727) I, 66 noot 1.

2. Ch. Nisard, Le triumvirat littéraire au XVIe siècle: Juste Lipse, Joseph Scaliger et Isaac Casaubon (Parijs, 1852) 73-74.

3. G. H. M. Delprat, Lettres inédites de Juste Lipse concernant ses relations avec les hommes d'état des Provinces-Unies des Pays-Bas principalement pendant les anneés 1580-1597. Publiées avec une introduction et des notes au nom de 1'Académie royale des Sciences àAmsterdam (Amsterdam, 1858) 31.

4. H. T. Oberman, 'Van Leiden naar Leuven. De overgang van Justus Lipsius naar eene Roomsche Universiteit', Nederlands Archief voor Kerkgeschiedenis, N.S., V (1908) 295-304.

5. H. van Crombruggen, Janus Lernutius (1545-1619). Een biografische studie. Verhandelingen van de Koninklijke Vlaamse Academie voor Wetenschappen, Letteren en Schone Kunsten van België, XXIII (1955) 63 noot 3.

6. G. Oestreich, 'Justus Lipsius in sua re', Formen der Selbstdarstellung. Analekten zu einer Geschichte des literarischen Selbstportraits. Festgabe für Fritz Neubert (Berlijn, 1956) 291-311. 